JEKPEND Jurnal Ekonomi dan Pendidikan

Volume 1 Nomor 2 Juli 2018. Hal. 15-22

p-ISSN: 2614-2139; e-ISSN: 2614-1973,

DOI: http://dx.doi.org/10.26858/jekpend.v1i2.7261

\title{
PENERAPAN STRATEGI PEMBELAJARAN AKTIF TIPE EVERYONE IS A TEACHER HERE (ETH) UNTUK MENINGKATKAN HASIL BELAJAR SISWA KELAS V SD INPRES BTN PEMDA KOTA MAKASSAR
}

\author{
Kadariah \\ Manajemen Pendidikan Universitas Terbuka, Makassar \\ Email: kadariah@ecampus.ut.ac.id
}

\begin{abstract}
This research is descriptive which generally aims (1) to know the description of the implementation of active learning strategy type 'Everyone is a Teacher Here' $($ ETH) in the learning of fifth grade students of SD Inpres BTN Pemda in Makassar City (2) to know the Implementation of Active Learning Strategy type 'Everyone is a Teacher Here' (ETH) in improving learning outcomes of fifth grade students of SD Inpres BTN Pemda in Makassar City. The subjects of this study were 40 students of fifth grade. Data collection techniques used are tests, observation and documentation. Data is processed with qualitative and quantitative descriptive analysis. Data in the form of observations of student activities and teacher activities during the learning process are analyzed qualitatively, and data on learning outcomes of class $\mathrm{V}$ students are analyzed quantitatively. The results of the study were used to see the problems that occurred in the school. This is because students are still less active and lack of interaction that occurs in the classroom both between students and teachers, and students and students in the learning process. So that student learning outcomes are still low. Based on the results of research and data analysis conducted shows that the level of student learning outcomes is quite optimal. Based on the individual minimum completeness criteria (KKM) agreed upon, each student must obtain a score of $\geq 75$. The fifth grade student learning outcomes referred to above show that in the initial implementation of teaching activities before the test showed (pre test) the average value of fifth grade students was 63.88 for all subjects. In the teaching implementation process with the implementation of Active Learning Strategy type Everyone is a Teacher Here (ETH) and carried out after the test (post test) showed the average value of fifth grade students increased to 79.86 or above the defined Minimum Examination Criteria (KKM). This shows an increase in learning outcomes of fifth grade students of SD Inpres BTN Pemda Makassar City.
\end{abstract}

Keywords: Active Learning Strategy type Everyone is a Teacher Here (ETH), Learning Outcomes

\begin{abstract}
Abstrak. Penelitian ini bersifat deskriptif yang secara umum bertujuan (1) Mengetahui gambaran Penerapan Strategi Pembelajaran aktif tipe Everyone is a Teacher Here (ETH) dalam pembelajan siswa kelas V SD Inpres BTN Pemda di Kota Makassar (2) Mengetahui Penerapan Strategi Pembelajaran aktif tipe Everyone is a Teacher Here $($ ETH) dalam peningkatan hasil belajar siswa kelas V SD Inpres BTN Pemda di Kota Makassar. Subjek penelitian ini adalah siswa kelas V sebanyak 40 orang siswa. Teknik pengumpulan data yang digunakan adalah tes, observasi dan dokumentasi. Data diolah dengan analisis deskriptif kualitatif dan kuantitatif. Data berupa hasil observasi aktifitas siswa dan kegiatan guru selama proses pembelajaran dianalisis secara kualitatif, dan data hasil belajar siswa kelas $\mathrm{V}$ dianalisis secara kuantitatif. Hasil penelitian untuk melihat masalah yang terjadi di sekolah tersebut. Hal ini dikarenakan siswa masih kurang aktif dan kurangnya interaksi yang terjadi dalam kelas baik antara siswa dan guru maupun antara siswa dan siswa dalam proses pembelajaran sehingga hasil belajar siswa masih rendah. Berdasarkan hasil penelitian dan analisis data yang dilakukan menunjukan bahwa tingkat hasil belajar siswa sudah cukup optimal, berdasarkan kriteria ketuntasan minimal (KKM) secara individu yang disepakati adalah setiap siswa harus memperoleh nilai $\geq 75$. Hasil belajar siswa kelas V yang dimaksud di atas menunjukan bahwa pada pelaksanaan awal kegiatan mengajar Pree Tes menunjukan nilai rata-rata siswa kelas V sebesar 63,88
\end{abstract}


untuk semua mata pelajaran, pada proses pelaksanaan mengajar dengan penerapan Strategi Pembelajaran aktif tipe Everyone is aTeacher Here (ETH) dan dilakukan Post Test menunjukan nilai rata-rata siswa kelas V naik menjadi 79,86 atau di atas Kriteria Ketuntasan Minmal (KKM) yang telah ditetapkan. Hal ini menunjukan adanya peningkatan hasil belajar siswa kelas V SD Inpres BTN PEMDA Kota Makassar.

\section{Kata Kunci: Strategi Pembelajaran aktif tipe Everyone is a Teacher Here (ETH), Hasil Belajar}

\section{PENDAHULUAN}

Pendidikan adalah usaha sadar menumbuhkembangkan potensi sumber daya manusia (SDM) melalui kegiatan pengajaran yang bertujuan membantu siswa dalam pengembangan dirinya secara optimal, yaitu pengembangan semua potensi,kecakapan serta karateristik pribadinya keaarah positif. Keberhasilan pencapaian tujuan pendidikan terutama ditentukan oleh proses pembelajaran yang dialami siswa. Dengan proses pembelajaran yang dialami siswa diharapkan adanya peningkatan pada aspek pengetahuan, sikap, dan ketrampilan siswa. Sebagaimana tercantum dalam Undang-Undang Republik Indonesia Nomor 20 Tahun 2003 Tentang Sistem Pendidikan Nasional Bab 1 pasal 1 poin 1 yaitu:

Pendidikan adalah usaha sadar dan terencana untuk mewujudkan suasana belajar dan proses pembelajaran agar peserta didik secara aktif mengembangkan potensi dirinya untuk memiliki potensi spiritual,keagamaan, pengendalian diri, kepribadian, akhlak mulia, serta ketrampilan yang diperlukan dirinya, masyarakat, Bangsa dan Negara.

Dalam kehidupan berbangsa dan bernegara pendidikan memiliki peranan yang sangat penting, yaitu untuk menjamin kelangsungan kehidupan dan perkembangan bangsa itu sendiri. Pendidikan merupakan sarana penting untuk meningkatkan kualitas sumber daya manusia (SDM) dalam menjamin kelangsungan pembangunan suatu bangsa. Peningkatan kualitas SDM jauh lebih mendesak untuk segera direalisasikan terutama dalam menghadapi persaingan global. Sebagaimana yang tercantum dalam Undang-Undang No.20 tahun 2003 tentang sistem dan Nasional menyatakan bahwa tujuan pendidikan nasional adalah mencerdaskan kehidupan bangsa dan mengembangkan manusia Indonesia seutuhnya yaitu manusia yang bertakwa terhadap Tuhan Yang Maha Esa dan berbudi pekerti luhur, memiliki pengetahuan dan ketrampilan, kesehatan jasmani dan rohani, kepribadian yang mantap dan mandiri serta tanggung jawab kemasyarakatan dan kebangsaan.

$$
\text { Kegiatan utama dalam proses }
$$

pendidikan di sekolah adalah kegiatan belajar mengajar. Siswa yang terlibat dalam proses belajar mengajar di harapkan mengalami perubahan baik dalam bidang pengetahuan, pemahaman, ketrampilan, nilai dan sikap. Dalam proses belajar mengajar guru akan menghadapi siswa yang mempunyai katateristik yang berbeda-beda sehingga guru tidak akan lepas dengan masalah hasil belajar

Keberhasilan dalam proses belajar mengajar di sekolah tergantung kepada beberapa aspek yaitu kurikulum, sarana dan prasarana, guru, siswa, dan metode. Aspek yang dominan dalam proses belajar mengajar adalah guru dan siswa. Kegiatan yang dilakukan guru dan siswa dalam hubungannya dengan pendidikan disebut kegiatan belajar mengajar. Untuk menciptakan suasana belajar siswa aktif, maka di perlukan pemilihan strategi pembelajaran yang tepat agar keaktifan siswa dapat terjadi

Penggunaan strategi dalam kegiatan pembelajaran sangat perlu karena untuk mempermudah proses pembelajaran sehingga dapat mencapai hasil yang optimal. Tanpa strategi yang jelas,proses pembelajaran tidak akan terarah. Untuk meningatkan proses belajar siswa, guru harus memilih dan menerapkan cara pembelajaran yang tepat untuk meningkatkan prestasi belajar siswa, tujuan ini akan tercapai jika guru terlibat langsung dalam proses pembelajaran, mampu menciptakan suasana belajar yang kondusif dan menyenangkan serta dapat memilih metode dan strategi pembelajaran tepat, variatif, sehingga dapat membangkitkan antusiasme siswa dalam belajar. Proses pembelajaran dapat dikatakan efektif apabila seluruh siswa terlibat secara langsung secara 
aktif, baik mental, fisik,maupun sosialnya (Mulyasa 2005:49)

Keadaan yang terjadi dilapangan berbeda dengan apa yang diharapkan. Pada kenyataannya berdasarkan hasil observasi di SD Inpres BTN PEMDA Kota Makassar siswa kelas $\mathrm{V}$ masih cenderung pasif dalam proses pembelajaran interaksi aktif baik antara guru dan siswa maupun antara siswa dengan guru yang masih tergolong kurang. Siswa lebih banyak melakukan aktifitas mencatat dan mendengarkan. Aktifitas bertanya, bertukar pendapat, menanggapi, maupun memamparkan pelajaran kepada teman-temannya masih sangat kurang sehingga pengetahuan yang diperoleh mudah dilupakan karena siswa hanya sekedar menulis dan mendengarkan tanpa pemahaman dan ketidakingintahuan terhadap materi pembelajaran. Hal ini tentu akan berdampak pada hasil belajar siswa tersebut. Dalam hal ini yang dilihat oleh peneliti adalah hasil belajar siswa pada ulangan ulangan yang dilaksanakan oleh guru-guru mereka.

Berdasarkan wawancara dengan guru setiap tengah semester selalu dilakukan ulangan tengah semester dan melihat hasil ulangan tersebut masih banyak siswa yang belum mencapai nilai kriteria ketuntasan minimal (KKM) 75 yang ditetapkan sekolah.

Usaha yang telah dilakukan oleh guru untuk meningkatkan hasil belajar siswa adalah memberikan tugas mandiri berupa mengerjakan soal soal yang diambil dari buku pegangan, LKS (Lembar Kerja siswa), atau membahas soal-soal yang menyangkut materi yang di ajarkan. Cara guru seperti ini dalam pembelajaran ternyata hasil belajar siswa masih rendah. Oleh sebab itu , perlu dilakukan strategi pembelajaran yang dapat mengaktifkan siswa dan mengembangkan kegiatan siswa dalam mengembangkan ide dan memecahkan masalah yang dihadapi siswa disaat belajar.

Peneliti memilih strategi pembelajaran aktif tipe Everyone is a Teacher Here (ETH) sebagai salah satu solusi yang dapat mengastasi permasalahan yang ada. Strategi ETH ini diharapkan dapat diterapkan dalam mengatasi permasalahan pembelajaran karena strategi pembelajaran ini merupakan strategi pembelajaran yang berpusat pada siswa yang mengutamakan keaktifan siswa dan memberikan kesempatan siswa untuk mengembangkan potensinya secara maksimal. Strategi ETH merupakan strategi yang berpusat kepada siswa dan layaknya bermain kuis dimana siswa tidak dibagi kelompok melainkan bekerja secara individu mereka bertanggung jawab dari awal kegiatan pembelajaran sampai akhir pembelajaran Tipe ETH memungkinkan siswa untuk berfikir apa yang dia pelajari, bertanya, menanggapi, dan membagi pengetahuan yang diperoleh siswa kepada siswa yang lain. Silberman (2006:183) menyatakan bahwa apabila siswa sudah dapat menjelaskan materi kepada siswa lainnya maka bisa dikatakan siswa tersebut telah menguasai materi pelajaran tersebut. Strategi ini memberikan kesempatan bagi setiap siswa untuk bertindak sebagai pendidik bagi siswa lainnya.

Strategi ETH ini dianggap tepat karena strategi ETH dapat melatih daya ingat, berfikir, dan melatih keberanian dalam berinteraksi dan ketrampilan siswa dalam proses pembelajaran di kelas. Materi bank dan lembaga keuangan bukan bank materi ini sangat berhubungan erat dengan kehidupan masyarakat sekarang ini sehingga dapat dikaitkan dengan strategi pembelajaran aktif tipe Everyone is a Teacher Here (ETH) karena dapat mengasah daya pikir siswa dan pendapatnya dengan apa yang ia alami dan lihat dalam kehidupan masyarakat sehari-hari. Sehingga siswa mendapat pengetahuan baru melalui interaksi dari jawaban maupun pendapat dari teman yang lainnya sesuai pengalaman maupun apa yang mereka pelajari.

Berdasarkan latar belakang yang dikemukakan diatas, maka rumusan masalah dalam penelitian ini adalah sebagai berikut : (1) Bagaimana penerapan strategi Pembelajaran aktif tipe Everyone is a Teacher Here (ETH); (2) Apakah penerapan strategi Pembelajaran aktif tipe Everyone is a Teacher Here (ETH) dapat meningkatkan hasil belajar siswa kelas V SD Inpres BTN Pemda Kota Makassar

\section{METODE PENELITIAN}

Penelitian ini dilakukan bertujuan untuk (1) Mengetahui gambaran Penerapan Strategi Pembelajaran aktif tipe Everyone is a Teacher Here (ETH) dalam pembelajan siswa kelas V SD Inpres BTN Pemda di Kota Makassar (2) Mengetahui Penerapan Strategi Pembelajaran aktif tipe Everyone is a Teacher Here (ETH) dalam peningkatan hasil belajar siswa kelas $\mathrm{V}$ SD Inpres BTN Pemda di Kota Makassar..

Pendekatan penelitian yang peneliti gunakan adalah pendekatan deskriptif kualitatif dan kuantitatif dengan menggambarkan secara deskriptif data yang diperoleh berupa hasil observasi aktifitas siswa dan kegiatan guru 
selama proses pembelajaran dengan menggunakan strategi pembelajaran aktif Everyone is a Teacher Here (ETH) data hasil belajar siswa kelas V SD Inpres BTN Pemda Kota Makassar yang dianalisis secara kuantitatif. Subjek penelitian ini adalah siswa kelas V SD Inpres BTN Pemda Kota Makassar dengan jumlah siswa 40 orang, yang terdiri dari 22 siswa laki-laki dan 18 siswa perempuan.

Untuk menjawab permasalahan yang ada dilapangan nantinya, maka variabel yang akan diteliti adalah sebagai berikut: (1) Variabel input yaitu Penerapan strategi pembelajaran aktif tipe Everyone is a Teacher Here (ETH); (2) Variabel proses yaitu melihat pelaksanaan Penerapan strategi pembelajaran aktif tipe Everyone is a Teacher Here (ETH); (3) Variabel Output yaitu melihat hasil belajar siswa kelas $\mathrm{V}$ melalui Penerapan strategi pembelajaran aktif tipe Everyone is a Teacher Here (ETH).

Adapun teknik pengumpulan data yang dilakukan dalam penelitian adalah; (1) observasi; (2) Wawancara; (3) Test, berupa soal-soal yang berkaitan dengan materi yang diajarkan baik sebelum diterapkan maupun setelah diterapkan; (4) dokumentasi.

Analisis data dalam penelitian ini dilakukan selama dan sesudah pengumpulan data. Data yang terkumpul dianalisis dengan Tabel 1. Kategori Hasil Belajar menggunakan analisis kauntitatif dan kualitatif. Data tentang hasil pengamatan aktivitas pembelajaran dianalisis secara kualitatif sedangkan data mengenai hasil belajar peserta didik dianalisis secara kuantitatif dengan menggunakan analisis deskriptif bertujuan untuk memberikan gambaran hasil belajar yang diperoleh peserta didik kelas V SD Inpres BTN Pemda Kota Makassar.

Data yang terkumpul yang diperoleh dari sampel penelitian, akan diolah/dianalisis dengan menggunakan teknik analisis deskriptif, yaitu prosentase $(\%)$, guna menjawab permasalahan yang telah dirumuskan pada bab terdahulu. Sesuai yang dikemukakan oleh Sugiyono (2009:43) yaitu:

$$
\mathrm{P}=\frac{F}{N} \times 100 \%
$$

Keterangan :

$\mathrm{F}=$ frekuensi yang sedang dicari persentasenya

$\mathrm{N}=$ Number of Cases (jumlah frekuensi/ banyaknya individu

$\mathrm{P}=$ Angka persentase

Kriteria yang digunakan untuk menentukan hasil belajar berdasarkan teknik kategorisasi skala lima. Berikut ini adalah pengkategorian hasil belajar sebagai berikut:

\begin{tabular}{c|c}
\hline Nilai Angka & Ketgori \\
\hline $90-100$ & Sangat Tinggi \\
$75-89$ & Tinggi \\
$60-74$ & Sedang \\
$35-59$ & Rendah \\
$0-34$ & Sangat Rendah \\
\hline
\end{tabular}

Sumber: SD Inpres BTN PEMDA Kota Makassar

Indikator keberhasilan penelitian ini terdiri atas dua jenis, yaitu indikator hasil belajar kognitif dan indikator proses. Berdasarkan indikator hasil belajar kognitif, penelitian ini dikatakan berhasil jika terjadi peningkatan hasil belajar peserta didik setelah diterapkannya strategi pembelajaran Everyone is a Teacher Here (ETH). Apabila terdapat $75 \%$ peserta didik yang mendapat nilai minimal 75 sesuai dengan KKM (Kriteria Ketuntasan Minimal) yang digunakan, maka kelas dianggap tuntas secara klasikal.

Sementara untuk indikator berikutnya, apabila frekuensi aktivitas siswa dalam proses pembelajaran meningkat setelah diterapkannya strategi pembelajaran aktif Everyone is a Teacher Here (ETH), maka dapat dikatakan bahwa proses belajar mengajar dengan strategi pembelajaran tersebut berhasil.

\section{HASIL DAN PEMBAHASAN}

Salah satu strategi pembelajaran yang melibatkan peran siswa secara aktif adalah strategi pembelajaran aktif tipe ETH. Strategi pembelajaran ini dapat diterapkan pada semua mata pelajaran tingkatan kelas, dan diperlukan pengelolaan manajemen kelas yang baik, strategi pembelajaran ini juga memberikan partisipasi seluruh kelas dan pertanggung jawaban individu untuk bertindak aktif di dalam kelas dan berani untuk mengemukakan pertanyaan maupun jawaban di dalam kelas.

Sejalan dengan penelitian terdahulu yang diungkapkan pada bab II yang 
dikemukakan oleh Marsanah pada (2010) mengatakan bahwa model pembelajaran Everyone is a Teacher Here (ETH) dapat meningkatkan keaktifan dan pemahaman materi. Hal ini diperkuat oleh hasil penelitian yang dilakukan oleh Munawaroh Nur Khafinah, dalam jurnal yang berjudul "Penerapan Model Pembelajaran Aktif Tipe Everyone Is a Teacher Here (ETH) untuk meningkatkan hasil belajar siswa pada mata pelajaran Sosiologi di kelas XI IPS 1 SMA Negeri 1 Pejagoan Tahun Pelajaran 2013/2014". Dari penelitian yang dilakukan selama dua siklus tersebut diperoleh kesimpulan bahwa model pembelajaran aktif tipe ETH dapat meningkatkan hasil belajar siswa, bukan hanya pada ranah kognitif atau pengetahuan saja, namun juga pada ranah afektif dan psikomotorik.

Beberapa hasil penelitian terdahulu juga diperkuat dengan Teori Belajar konstruktivisme. Teori Konstruktivisme ini menyatakan bahwa siswa harus menemukan sendiri, dan mentransformasikan informasi kompleks, mengecek informasi baru dan aturan-aturan lama dan merevisinya apabila aturan-aturan itu tidak lagi sesuai. Menurut teori ini juga, siswa sebagai pemain dan guru sebagai fasilator yang mendorong siswa dalam mengembangkan potensinya secara optimal. Salah satu cara dengan melibatkan siswa berperan aktif dikelas baik dalam membuat pertanyaan untuk temannya, berani bertanya, menanggapi, maupun tampil memaparkan jawaban dan menjelaskan kepada teman-temannya.

Selain Teori Konstruktivisme, Penelitian ini juga berangkat dari teori Perkembangan Kognitif Piaget. Teori Perkembangan Piaget mewakili konstruktivisme, yang memandang perkembangan kognitif sebagai suatu proses dimana anak secara aktif membangun sistem makna dan pemahaman realitas melalui pengalaman-pengalaman dan interaksi mereka.

Kedua Teori tersebut dianggap sangat sesuai dengan proses dan hasil penelitian terdahulu yang dikemukakan diatas. Alasannya adalah pertama, Teori Konstruktivisme ini membuat seluruh siswa bertindak aktif dikelas dan diberikan tanggung jawab untuk menjawab dan menjelaskan pertanyaan kepada temantemannya sehingga siswa termotivasi untuk memahami dan menguasai materi yang diberikan oleh guru. Kedua, untuk Teori Perkembangan Kognitif Piaget siswa dapat membangun potensi dirinya dan berani berinteraksi dengan siswa lainnya dalam berargumen, bertanya, maupun menanggapi sehingga siswa dapat memperoleh pengetahuan tambahan melalui hasil interaksi dikelas pada proses pembelajaran sehingga siswa bisa mengingat dan memahami materi pelajaran tersebut.

Sesuai dengan penelitian terdahulu dan hasil penelitian yang diperoleh tergambar jelas apa yang dimaksudkan dari kedua teori tersebut. Dengan demikian Everyone is a Teacher Here (ETH) dapat meningkatkan hasil belajar siswa baik dari segi pengetahuan, pemahaman, maupun tingkah laku dalam proses pembelajaran di kelas. Adapun gambaran hasil penelitian berdasarkan penerapan strategi pembelajaran aktif tipe everyone is a teacher here (ETH) untuk meningkatkan hasil belajar Siswa kelas V SD Inpres BTN PEMDA Kota Makassar sebagai berikut:

\section{Aktivitas Guru}

Guru dalam melaksanakan kegiatan pembelajaran sepenuhnya sesuai dengan perencanaan pembelajaran. Dari hasil observasi pengamat, hal ini karena guru lebih banyak di depan kelas dan kurang memberikan motivasi dan pengarahan kepada siswa bagaimana melakukan strategi pembelajaran Everyone is a Teacher Here (ETH) serta menyimpulkan materi pembelajaran diakhir pelajaran hal ini disebabkan karena perhatian peneliti yang tidak merata kepada setiap siswa. Sehingga dengan adanya kekurangan pada pembelajaran awal, sehingga peneliti berupaya untuk mengadakan perbaikan dan memaksimalkan pada pembelajaran selanjutnya dengan upaya yakni; 1) Pemberian motivasi kepada Siswa, 2) lebih mengawasi jalannya kegiatan pembelajaran dengan menggunakan strategi ETH. 3) Membimbing siswa dalam menyimpulkan materi pembelajaran.

Setelah melakukan proses pembelajaran tahap ke dua, perkembangan aktivitas guru dari tahap awal ke tahap ke dua, menunjukan adanya peningkatan dalam setiap pertemuan pada tahap ke dua. Ini terlihat dari setiap indikator yang tercapai. Hal ini disebabkan karena guru sudah intensif dalam membimbing siswa yang mengalami kesulitan dan meningkatnya aktivitas peneliti dalam mempertahankan dan meningkatkan suasana pembelajaran Everyone is a Teacher Here (ETH).

\section{Aktivitas Siswa}

Pada proses pembelajaran awal, belum sepenuhnya tercapai, hal ini disebabkan karena; 1) sebagian siswa masih malu untuk mengeluarkan pendapat atau gagasannya maupun mengajukan pertanyaan di dalam kelas. 
2) Sebagian siswa juga masih bingung dengan kegiatan pembelajaran menggunakan strategi pembelajaran Everyone is a Teacher Here (ETH) sehingga sebagian siswa masih kaku dalam beraktivitas di kelas. Permasalahan lain adalah masih banyak siswa yang melakukan aktifitas lain dan tidak fokus pada pelajaran di kelas. Dari hal ini dapat dikatakan ketercapaian setiap indikator belum maksimal, Sehingga penelitian ini harus dilanjutkan ke tahap selanjutnya.

Setelah pelaksanaan pada proses pembelajaran dengan penerapan strategi pembelajaran Everyone is a Teacher Here (ETH), aktivitas siswa secara umum meningkat. Hal ini dapat dilihat dari jumlah frekuensi dan presentase setiap pertemuan yaitu dari proses pembelajaran awal pertemuan pertama dan kedua, ke proses pembelajaran selanjutnya pertemuan pertama dan kedua, hal ini disebabkan karena siswa sudah mengalami keaktifan belajar dalam pelaksanaan strategi pembelajaran aktif tipe ETH sehingga siswa sudah berani mengeluarkan pendapat atau gagasan maupun bertanya apabila belum mengerti apa yang disampaikan oleh temannya maupun yang disampaikan oleh guru. Dalam proses pembelajaran setiap siswa sudah memahami langkah-langkah strategi pembelajaran aktif tipe ETH dengan baik sehingga siswa terlihat bersemangat dalam proses pembelajaran. Sehingga dengan demikian hasil observasi terhadap aktivitas siswa.

\section{Hasil Belajar Siswa}

Perkembangan hasil belajar siswa dalam proses pembelajaran melalui strategi pembelajaran aktif tipe Everyone is a Teacher Here (ETH) bahwa hasil belajar siswa dari tes awal sebelum penerapan strategi sampai pada penerepana strategi pembelajaran Everyone is a Teacher Here (ETH), mengalami peningkatan yang signifikan. Jumlah siswa yang dalam kategori tuntas setiap proses pembelajaran mengalami peningkatan dan sebaliknya siswa yang berada pada kategori tidak tuntas setiap proses pembelajaran dengan penerapan strategi tersebut mengalami penurunan. Hal ini menunjukan bahwa penerapan strategi pembelajaran aktif tipe Everyone is a Teacher Here (ETH) dapat meningkatkan hasil belajar siswa kelas V SD Inpres BTN PEMDA Kota Makassar.
Pada proses pembelajaran awal, sebelum dilakukan penerapan strategi pembelajaran diperoleh skor tertinggi yaitu 85 dan skor terendah 40, rata-rata hasil belajar sebesar 63,88 dan berdasarkan tabel distribusi frekuensi, diperoleh hasil belajar siswa melalui strategi pembelajaran aktif tipe ETH sebanyak 0,00 persen atau tidak ada siswa yang berada pada kategori sangat tinggi, 30,00 persen atau 12 orang siswa berada pada kategori tinggi, 40,00 persen atau 16 orang siswa berada pada kategori sedang, 30,00 persen atau 12 orang siswa berada pada kategori rendah, 0,00 persen siswa berada pada kategori sangat rendah.

Adapun ketuntasan belajar siswa secara klasikal baru mencapai 30,00 persen atau 12 orang siswa. Hal ini memberi indikasi bahwa hasil belajar siswa sebelum pelaksanaan penerapan strategi pembelajaran Everyone is a Teacher Here (ETH) mengalami peningkatan, tetapi belum mencapai indikator keberhasilan pembelajaran yang diharapkan yaitu ketuntasan inidividu pada hasil ujian nilai 75 (sesuai dengan KKM) dan kentutasan secara klasikal minimal 75 persen dari jumlah keseluruhan siswa dalam kelas yang mencapai ketuntasan, sehingga perlu dilaksanakan proses pembelajaran selanjutnya.

Penerapkan strategi pembelajaran aktif tipe ETH dengan lebih baik lagi. Pada pembelajaran selanjuntnya sudah dilakukan penerapan strategi pembelajaran Everyone is a Teacher Here (ETH), sehingga hasil ujian diperoleh sebanyak 7,50 persen atau 3 orang siswa yang berada pada kategori sangat tinggi, 75,00 persen atau 30 orang siswa berada pada kategori tinggi, 17,50 persen atau 7 orang siswa berada pada kategori sedang, 0,00 persen atau tidak ada siswa yang berada pada kategori rendah, dan 0,00 persen atau tidak ada siswa berada pada kategori sangat rendah.

Adapun ketuntasan belajar siswa secara klasikal mencapai 82,50 persen atau 33 orang siswa yang telah tuntas secara individu. Sehingga dari data hasil belajar siswa sebelum tindakan (sebelum menggunakan strategi pembelajaran ETH) dan setelah tindakan (setelah menggunakan strategi pembelajaran ETH) mengalami peningkatan dan mencapai indikator keberhasilan yang ditentukan yaitu minimal 75,00 persen dari jumlah siswa dalam kelas telah mencapai ketuntasan individual yaitu 75 (Sesuai dengan $\mathrm{KKM}$ ). 


\section{SIMPULAN DAN SARAN \\ Simpulan}

Berdasarkan hasil penelitian dari analisis data penelitian maka dapat ditarik beberapa simpulan yang dapat dikemukakan sebagai berikut :

1. Melalui penerapan strategi pembelajaran aktif tipe Everyone is a Teacher Here (ETH) dapat meningkatkan aktivitas dan kemampuan guru dalam proses pelaksanaan belajar mengajar di setiap proses pembelajaran.

2. Berdasarkan hasil observasi yang telah dilakukan, terdapat perubahan dan peningkatan kemampuan aktivitas siswa dalam proses pembelajaran pada siswa kelas V SD Inpres BTN Pemda Kota Makassar setelah penerapan Everyone is a Teacher Here (ETH).

3. Melalui penerapan strategi pembelajaran aktif tipe Everyone is a Teacher Here (ETH) dapat meningkatkan hasil belajar siswa kelas V SD Inpres BTN Pemda Kota Makassar.

Saran

Sehubungan dengan hasil penelitian yang telah dikemukakan sebelumnya serta implikasinya, maka berikut ini dikemukakan saran sebagai berikut:

1. Bagi sekolah, model pembelajaran dengan strategi pembelajaran aktif tipe ETH dapat dijadikan salah satu model pembelajaran yang dapat diterapkan dalam proses pembelajaran.

2. Bagi Guru, dapat menggunakan strategi pembelajaran aktif tipe ETH untuk mengaktifkan proses pembelajaran di kelas dan juga untuk meningkatkan hasil belajar siswa di kelas V Sekolah Dasar.

3. Bagi Peneliti, agar terus meningkatkan dan memperkuat hasil penelitiannya dengan melakukan kajian lebih terhadap strategi pembelajaran ini, serta diharapkan pula agar terus mengembangkan diri dalam dalam melakukan penelitian dengan strategi pembelajaran yang lebih bervariasi lagi.

\section{DAFTAR RUJUKAN}

Bellanca James. 2011. 200+ Strategi-Strategi dan Proyek Pembelajaran aktif. Jakarta Barat: PT. Indeks Permata Puri Media.

Dimyati dan Mujiono. 2002. Belajar dan Pembelajaran. Jakarta : PT. Raja Grafino Persada.
Haling Abd, Parumbuan, Pattaufi, Arsal, Nurhikmah, Arnidah, Febrianti, Faridah 2007. Belajar dan Pembelajaran. Makassar: FIP UNM.

Hamalik, Oemar. 2003. Kurikulum dan Pembelajaran. Jakarta: Bumi Aksara.

Marsanah. 2010. Penerapan strategi pembelajaran aktif tipe Everyone is a Teacher Here (ETH) untuk meningkatkan prestasi belajar ekonomi siswa kelas X-2 SMA YLPI Marpoyan Pekanbaru. Skripsi FKIP Universitas Riau.

Mudyaharjo, Redja. 2014. Pengantar Pendidikan. Jakarta : PT. Rajawali Pers

Musfah Jejen. 2015. Manajemen Pendidikan. Jakarta: Prenamedia Group.

Paizaluddin \& Ermalinda. 2013. Penelitian Tindakan Kelas (Classroom Action Research): Panduan Teoritis dan Praktis. Bandung: Penerbit Alfabeta.

Purwanto. 2011. Evaluasi Hasil Belajar. Yogyakarta: Pustaka Pelajar.

Rusman. 2013. Model-model Pembelajaran: Mengembangkan Profesionalisme Guru. Edisi Kedua. Jakarta: Rajawali Pres.

Sanjaya, Wina. 2012. Strategi Pembelajaran Berorientasi Standar Proses Pendidikan. Jakarta: Kencana.

Sanjaya, Wina. 2014. Strategi Pembelajaran Berorientasi Standar Proses Pendidikan. Jakarta: Kencana.

Silberman. 2006. Active Learning Strategi :101 Cara Belajar Aktif. Terjemahan Raisul Muttaqin.Bandung: Nusamedia.

Sudijono, Anas. 2011. Pengantar Statistik Pendidikan. Jakarta: Rajawali Pers.

Susanto Ahmad. 2013. Teori belajar dan pembelajaran di sekolah dasar. Jakarta: PT. Fajar Interpratama Mandiri.

Suprijono, Agus. 2009. Cooperative Learning: Teori dan Aplikasi PAIKEM. Surabaya: Pustaka Belajar.

Trianto. 2013. Mendesain Model Pembelajaran Inovatif-Progresif: Konsep, Landasan,dan Implementasinya pada Kurikulum Tingkat Satuan Pendidikan (KTSP). Edisi Pertama. Jakarta: Kencana.

Uno Hamzah B. 2012. Model pembelajaran Menciptakan Proses Belajar mengajar 
yang kreatif dan efektif. Jakarta: PT. Bumi Aksara

Uno Hamzah B \& Mohamad Nurdin, 2010. Belajar dengan pendekatan PAIKEM: Pembelajaran Inovatif ,Kreatif, Menarik dan Menyenangkan. Jakarta: PT.Bumi Aksara.
Usman, Uzer. Moh. 2013. Menjadi Guru Profesional. Edisi Kedua. Bandung PT Remaja Rosda karya.

Warsono \& Hariyanto. 2012. Pembelajaran Aktif, Edisi Kedua. Bandung: PT. Remaja Rosda karya

Wena, Made. 2014. Strategi pembelajaran inovatif kontemporer. Jakarta: PT. Bumi Aksara 